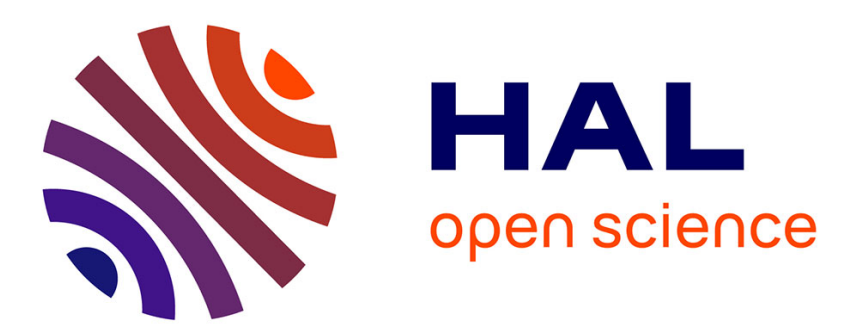

\title{
Microbiotic soil crusts in the Sahel of Western Niger and their influence on Soil POROSITY and water dynamics
}

Oumarou Malam Issa, Christian Défarge, Jean Trichet, C. Valentin, J.L. Rajot

\section{To cite this version:}

Oumarou Malam Issa, Christian Défarge, Jean Trichet, C. Valentin, J.L. Rajot. Microbiotic soil crusts in the Sahel of Western Niger and their influence on Soil POROSITY and water dynamics. CATENA, 2009, 77 (1), pp.48-55. 10.1016/j.catena.2008.12.013 . insu-00338694

\section{HAL Id: insu-00338694 https://hal-insu.archives-ouvertes.fr/insu-00338694}

Submitted on 14 Nov 2008

HAL is a multi-disciplinary open access archive for the deposit and dissemination of scientific research documents, whether they are published or not. The documents may come from teaching and research institutions in France or abroad, or from public or private research centers.
L'archive ouverte pluridisciplinaire HAL, est destinée au dépôt et à la diffusion de documents scientifiques de niveau recherche, publiés ou non, émanant des établissements d'enseignement et de recherche français ou étrangers, des laboratoires publics ou privés. 
Microbiotic soil crusts in the Sahel of Western Niger and their influence on Soil POROSITY and water dynamics

Malam Issa O. ${ }^{1,{ }^{*}}$, Défarge C. ${ }^{2}$, Trichet J. ${ }^{2}$, Valentin C. ${ }^{3}$ and Rajot J-L. ${ }^{3}$

(1) Université de Reims Champagne-Ardenne, GEGENA EA 3795, CREA 2 Esplanade Roland Garros, 51100 Reims, France

(2) ISTO, UMR 6113 CNRS-Université d’Orléans, BP 6759, 45067 Orléans cedex 2, France

(3) UR "Solutions" Institut de Recherche pour le Développement - IRD Centre de Recherche de l'Ile de France 32, av. H. Varagnat 93143 Bondy cedex

*Corresponding author: Email: $\underline{\text { Oumarou.Malam-Issa@orleans.inra.fr }}$

\begin{abstract}
Microbiotic soil crusts are common features of the surface of fallow land in Western Niger. We investigated the interaction between these microbial covers and the porosity and water dynamics of soils at the surface of a Sahelian landscape. The soil pore system was examined by microscopic observations and mercury porosimetry. The soil water retention capacity was measured using a Richard pressure membrane apparatus. Runoff measurements were performed in situ at a one $\mathrm{m}^{2}$ scale under natural rainfall.

Samples with dense cyanobacterial cover had microbially-originated pores ranging from 0.04 and $50 \mu \mathrm{m}$ in size. These samples also showed higher total soil porosity and retained two to four times more water than samples with thin microbial cover. These
\end{abstract}


properties are closely related to the hydrophobic nature of cyanobacterial components. Final runoff values obtained on densely covered surfaces were significantly higher compared to those measured on surfaces with thin microbial cover due to the geometry of the microbially-originated pore system and its functioning.

Keywords: Microbiotic crusts; Cyanobacteria; Exopolysaccharides; Pore geometry; Erosion; Runoff; Water retention; Sahel.

\section{INTRODUCTION}

Microbiotic soil crusts result when communities of extremely drought-resistant microorganisms, dominated by cyanobacteria, colonise the soil surface. These crusts are commonly found in arid environments where the vegetation cover is sparse. In the Sahel of Western Niger (West Africa), microbiotic soil crusts are essential components of fallow land and "tiger bush" ecosystems (landscapes of alternating bands of vegetation and bare ground aligned along the contours; Valentin et al., 1999; Malam Issa et al., 1999). They occur as a surficial organo-mineral soil layer, usually associated with physical soil crusts, i.e. soil surfaces with a compacted structure, favourable to runoff and interrill erosion (Valentin, 1995; Ambouta, 1997). Field observations showed that microbiotic soil crusts control the development of physical crusting and the subsequent removal of particles. These observations were supported by laboratory studies of soil aggregate stability and micromorphological characteristics, which demonstrated the prominent role played by microbiotic crusts in soil particle aggregation (Malam Issa et al., 1999; 2001). 
Despite the abundant literature, the hydrological processes taking place at the surface of microbiotic soil crusts are far from being well understood (Belnap, 2006). In some cases, lower infiltration rates were observed for soils with microbial cover compared to soils with low levels or no microbial cover (Kidron et al., 1999; Eldridge et al., 2000; Yair, 2001; Li et al., 2002, Maestre et al., 2002), while in other circumstances the presence of microbiotic soil crusts led to either positive effects (Loope and Gifford, 1972; Belnap and Gardner, 1993; and Pérez, 1997) or had no effect on water infiltration in soil (Eldridge et al., 1997 and Williams et al., 1999). More recently, literature reviews from Australia, Israel and North America argued that these discrepancies result from a combination of factors related to methodological approaches, rainfall characteristics, soil factors and the biological composition of crusts (Eldridge, 2001; Warren, 2001; Yair, 2001). According to Belnap (2006), data related to soil bulk density, micro- and macropores and the structure of biological crusts are needed to provide insight into the mechanisms explaining how microbiotic soil crusts affect infiltration and runoff. Soil characteristics, such as porosity, may affect water transit through the soil, depending on the connectivity and the size of pores. However, little information is available in the literature about the porosity system of microbiotic soil crusts, which was quantitatively investigated in only a few cases (Verrecchia et al., 1995).

Thus, in the present work we focused on soil porosity, runoff and the water retention capacity of soils with microbiotic crusts in Sahelian environments. The study aimed at highlighting soil hydrological processes at the surface of microbially covered soils in a Sahelian ecosystem. The methodological approach was based on comparisons between microbial soil crusts of varied cover and the horizon beneath these crusts. 
Results of in-situ runoff measurements are discussed in light of microscopic investigations and laboratory measurements of soil porosity and water retention capacity.

\section{MATERIALS AND METHODS}

The study site

The study site is located near the village of Banizoumbou in the western region of Niger (Sahel), $70 \mathrm{~km} \mathrm{NE}$ of Niamey, the capital city.

The landscape is composed of three major geomorphic units (Fig. 1; Valentin, 1995; Courault et al., 1990):

- a plateau, formed by Tertiary fluvio-lacustrine deposits ('Continental terminal'; Greigert, 1966), which is dissected into several sections by erosion and has a slight slope with a maximum of one percent ( Fig. 1; Ambouta, 1997). The plateau vegetation shows a characteristic pattern of alternating densely vegetated bands, comprising small trees and shrubs, and bare soil. The landscape structure is controlled by the downward movement of water and is called 'tiger bush' (Ambouta, 1984; Cornet, 1992; Malam Issa et al., 1999).

- sand dunes formed by Pleistocene stabilised-sand with a mean slope of approximately two to five percent (Fig. 1). These are used for cropping pearl millet and cowpea, and support vegetation areas used for pasture during fallow periods.

- valley systems, formed by aeolian, colluvial and fluvial sands, comprise broad sand plains or sand-filled stream beds with a mean slope of three to five percent (Fig. 1). These are also used for cropping millet and cowpea. 
The climate is typical of the southern Sahel, with a single rainy season lasting, roughly, from May to mid October. Total annual rainfall amounted to 529 mm in 1996 and 534 mm in 1997. These values are slightly below the long-term average of approximately 560 mm (Le Barbé and Lebel, 1997).

Runoff was measured during the 1996 rainy season from July 16th to October 12th. Daily rainfall varied from 0.5 to $69.5 \mathrm{~mm}$ (fig. 2a, $13.4 \mathrm{~mm}$ in average) and lasted from 93 to 160 minutes. The rainfall intensity recorded within the first minute and after 10 minutes of rain ranged from 64 to $86 \mathrm{~mm} / \mathrm{h}$ and 37 to $55 \mathrm{~mm} / \mathrm{h}$, respectively. In total, 33 events occurred during the 1996 rainy season. Runoff measurements were made for approximately 20 events.

\section{Experimental Field parcels}

The experimental parcels were located within the sand dune geomorphic unit (Fig. 1). The textural characteristics of soils in this area are shown in table 1 . These consisted of poorly aggregated sandy materials of low organic matter content, which are consequently prone to physical crusting. All the experimental parcels were protected from animal disturbance and human activity. They were cut and treated with preemergent herbicides to prevent plant growth. The parcels were classified into two types depending on the age of fallow and their initial microbial cover: "densely covered” or “thinly covered” surfaces. Densely covered surfaces comprised three parcels of nine $\mathrm{m}^{2}$ located on an area kept fallow and undisturbed for 3 years (a1, b1, c1; Table 2). The percentage of microbial cover ranged from 75 to $80 \%$ (Table 2). Thinly covered surfaces comprised three similar experimental parcels located on 1-year fallow and supporting early stages of microbial cover (a2, b2, d2; Table 2). Existing crusts 
(physical and microbial) were mechanically destroyed to obtain an initial stage of crust formation. The initial percentage of microbial cover ranged from 10 to $30 \%$ (Table 2).

\section{In situ measurements}

Field experiments entailed observations and visual estimations of soil surface cover, as well as measurements of runoff under natural rainfall. A runoff plot was set up inside each experimental parcel by using a five centimetre high metallic frame. The metallic frame used to isolate the runoff plot included a collector system to catch runoff water and soil particles removed from the area. The collector system was formed by a gutter located at the downslope side of the frame, connected to a tank by a pipe. Runoff was measured by determining the amount of rainfall, with a pluviograph located next to the experimental field, and the volume of water which flowed out of the plots following rainfall events.

The soil surface cover inside the runoff plots was measured using the point-quadrats method. The experimental plots were divided into 100 areas of $0.01 \mathrm{~m}^{2}$ each. A total of five crust features grouped into microbial or physical types were defined on the basis of visual criteria. Soil surface cover was estimated for the initial surface and at three occasions throughout the rainy season.

\section{Laboratory analyses}

Two types of samples were analysed in the laboratory. The first type was a sample of microbial cover obtained by removing the superficial layer (ca. 2-5 mm thick), comprising living microorganisms, with a knife. The second type was devoid of

microbial cover and samples were made by collecting soil from the underlying soil horizon of areas with microbial cover, and from the bare surface of recent fallow land. 
The water retention capacity, porosity and micromorphological characteristics of the two sample types were investigated. The soil water retention capacity was determined using a Richard pressure membrane apparatus. The samples were submitted to $\mathrm{pF} 2.5$ and 4.2. The water retained was measured by weighing the samples before and after the experiments. Mercury porosimetry experiments were performed with a Micromeritics 9310 porosimeter with an operating pressure between 0.003 and 200 MPa. The surface tension and contact angle between the mercury and the soil material were $4.84 \mathrm{~N} \cdot \mathrm{m}^{-1}$ and $130^{\circ}$, respectively. The micromorphological characteristics of dry and wet samples with microbial cover were investigated using a JEOL JSM 6400 SEM and a high resolution Hitachi S-4200 SEM equipped with a Polaron LT 7400 cryopreparation system (Cryo-SEM).

\section{Statistical analyses}

Statistical analyses were made using XLSTAT 2006 (ADDINSOFT TM, Paris, France). In order to compare runoff height and ratio from different plots, an analysis of covariance (ANCOVA) was performed, with runoff as the dependent variable and microbial cover and rainfall as covariates. Multiple comparison tests (Tuckey's HSD) were used to test for significant differences in water retention capacity and porosity obtained for samples with dense and thin microbial cover and bare samples.

\section{RESULTS}

In situ observations of soil surface cover

The results of our estimations of the soil surface covered by microbial crusts are shown in Table 2. During the rainy season, for densely covered soils, the area covered 
by microbial surface crust decreased from its initial value (75-80 \%) to final values between 32 and $39 \%$ (Table 2). The percentage of microbial cover on thinly covered parcels also decreased from initial values (10-30 \%) to 3-12 \% at the beginning, and then $0-8 \%$ at the end of the rainy season (Table 2).

\section{Rainfall and Runoff measurements}

Runoff was measured under rainfall intensities ranging from 3.5 to $48.5 \mathrm{~mm} \mathrm{~h}^{-1}$. The depth of runoff from the different experimental plots was between 0 and $39 \mathrm{~mm}$ (fig. 2b). Values measured at the surface of densely covered plots ranged from 0 to $37 \mathrm{~mm}$ ( $8.3 \mathrm{~mm}$ in average) vs. 0 to $39 \mathrm{~mm}$ (6.6 $\mathrm{mm}$ in average) at the surface of thinly covered plots. Runoff coefficient values ranged from 2 to $95 \%$ (39\% in average) at the surface of dense covered plots vs. 0 to $93 \%$ (28\% in average) at the surface of thinly covered surfaces. Statistical comparison tests (ANCOVA and Tukey HSD) of the results showed that runoff was significantly higher, at the $95 \%$ confidence interval, on plots with dense

microbial cover than on thinly covered plots. No runoff was detected for rainfall below $3.5 \mathrm{~mm} \mathrm{~h}^{-1}$. More runoff was produced from both plot types when a greater quantity of rain fell during each rainstorm (fig. 2b). The x-intercepts of runoff and rainfall curves were different for densely covered and thinly covered plots. Values of x-intercepts obtained for the surface of densely covered plots (fig. 2b) were lower than those obtained for thin plots (fig. 2b), which means that runoff was generated earlier at the surface of densely covered plots compared to thinly covered plots.

Water retention capacity measurements 
The percentage of water retained by samples with dense microbial cover at $\mathrm{pF}$ 2.5 ranged from 12 to $14 \%$ (mean $13 \% \pm 0.7$, table 3 ). These water retention capacity values were significantly higher, at $95 \%$ confidence intervals, than those of thinly covered samples (mean $7 \% \pm 0.5$ ). The water retention capacity of samples with dense microbial cover was also significantly higher than that of samples lacking microbial cover, i.e. horizon underlying the crust (3 to $4 \%$, mean $3 \% \pm 0.6$, table 3 ). The water retention capacity values at $\mathrm{pF} 4.2$ were not significantly different between samples with or without microbial cover. Water retention values at pF 4.2 ranged from 2 to $4 \%$ (table 3, average $3 \% \pm 0.7$ ), and 2 to $3 \%$ (table 3 , average $2 \% \pm 0.3$ ) for soils samples with, and without microbial cover, respectively.

\section{Mercury porosimetry}

The mean values of total pore volume ranged from 207 to $287 \mathrm{~mm}^{3} \mathrm{~g}^{-1}$ and 212 to $233 \mathrm{~mm}^{3} \mathrm{~g}^{-1}$ for samples with and without microbial cover, respectively (fig. 3). The mean values for total pore volume were significantly higher for samples with dense microbial cover compared to those with thin cover and the horizon underlying the crusts (fig. 3, table 3). No significant difference was observed between thin cover samples and samples from underneath the crust. The pore diameter corresponding to the maximum mercury intrusion was between 8.5 to $15 \mu \mathrm{m}$ for samples with microbial cover and 27 to $35 \mu \mathrm{m}$ for samples from the underlying horizons (fig. 3).

The cumulative pore volume curves (cpv) displayed different trends between samples (fig. 3). Mercury entry was continuous into pores between 0.006 and $400 \mu \mathrm{m}$ in samples with dense microbial cover (fig. 3). On the contrary, samples from soil with thin cover and crust-underlying horizons showed no or very little mercury entry for pores between 0.06 and $10 \mu \mathrm{m}$ (fig. 3). 


\section{Micromorphological observations}

The surface of bare samples was composed essentially of rounded quartz grains with rare fine particles, whereas soils with microbial cover showed a superficial network formed by cyanobacterial filaments (F, fig. 4) and extracellular polymer secretions (EPS, fig. 5). The soil pore system and particle organisation differed between samples from soil with dense microbial cover, and samples from thin cover and bare soils. Soil with dense microbial cover showed round-shaped pores up to 50-60 $\mu \mathrm{m}$ in diameter (arrows, fig. 4) and elongated angular-shaped pores with variable diameters (fig. 4), both resulting from the rearrangement of filaments and EPS at the surface. At depth, pores appeared to be caused by cyanobacteria filaments growing in the grain inter-spaces (F, fig. 6a) and gluing these together, as well as causing finer soil particles to adhere together (Mc, fig. 6). Pores in soils with low microbial cover were essentially formed by the spaces between sand particles (V, top part of fig. 6b), partially filled with fine particles (Pl, fig. 6b) and sparse filaments (F, fig. 6b). The profile underlying the crust showed a more porous structure, comprised of tubular and interconnected packing voids partially filled with fine particles, and vesicular and round-shaped pores formed by particle compaction (see bottom part of fig. 6a and b). These pores were similar to those found in bare samples.

The behaviour of the microbial cover upon wetting is illustrated in figures 3a. B. Cyanobacteria of the genus Nostoc showed a spectacular increase in colony volume during rewetting, when the mean diameter of the colonies grew from 50-100 $\mu$ m to 150$250 \mu \mathrm{m}$. The same behaviour was previously reported for other cyanobacterial strains 
(Schizotrix), with the mean diameter of individual filaments growing from 10-15 $\mu \mathrm{m}$ to 15-20 $\mu \mathrm{m}$ (Défarge et al., 1999).

\section{DISCUSSION}

Micromorphological structure of microbial crusts

Using mercury porosimetry, we observed a significant difference between the pore system of samples with dense microbial cover and samples from soil with either thin cover or from the horizon underlying the crust (fig.3). Samples with dense microbial cover contained large pore volumes, and mercury entered, gradually and continuously, through pores of 400 to $0.006 \mu \mathrm{m}$ in size (fig. 3; table 3). In contrast, the extent of mercury entry in samples of soil devoid of microbial cover and soil with thin microbial cover was low and discontinuous between 10 and $0.04 \mu \mathrm{m}$ (fig. 3; table 3). Verrecchia et al. (1995) reported similar results with mercury porosimetry, and found a higher proportion of small size pores (4 to $40 \mu \mathrm{m}$ in size) in sandy soils with microbiotic crusts compared to sandy soils without these crusts.

Characterisation of the micromorphology of the samples also suggests that cyanobacterial cover is inducing differences in the soil pore system and soil particle organisation (fig. 4 and 5). Soils from thin cover parcels mainly showed elongated and rounded pores that are similar to those found in the sub-crust and bare soils. These pores result from packing of sand and silt particles, infilling by finer particles, compaction due to raindrop impacts and, to some extent, faunal activities and the action of plant roots (Valentin and Bresson, 1992; Malam Issa et al., 1999). These mechanisms likely formed the main pores revealed by mercury porosimetry in soils with thin cover, whose sizes ranged from 100 to $400 \mu \mathrm{m}$. On the contrary, soils with dense microbial cover showed additional pores, with elongated and rounded shapes and various diameters, ranging 
between 0.04 and $50 \mu \mathrm{m}$ (fig. 4). These pores are caused essentially by bacterial filaments which are interwoven in a superficial network; additional pores are formed by the remaining spaces between adjoining filaments (fig. 4). The occurrence of these pores may be related to the physico-chemical properties of cyanobacterial material, which include polymers of hydrophilic and hydrophobic molecules (Stanier and CohenBazire, 1977; Decho, 1990; Kidron et al., 1999). The hydrophilic molecules are polysaccharides, known as adhesive exopolymers that help microbial cells to maintain an association with other cells and the physical environment (Decho, 1990). The hydrophobic molecules are glycoproteins and lipopolysaccharides; these increase the adhesive forces between adjoining filaments (Kidron et al., 1999; Malam Issa et al. 2001). Both hydrophilic and hydrophobic components confer adhesive properties to cyanobacterial material; these properties control the ability of filaments to adhere to one another and bind soil particles, and hence affect the soil's spatial organisation. The number of microbial pores appeared to increase with the complexity of the superficial network suggesting that the presence and geometry of the pores observed in the microbiotic soil crusts are directly affected by cynaobacteria derived polysaccharides. Thus, the difference in pore systems between the two types of soil samples, revealed by mercury porosimetry, reflects the presence of micropores derived from cyanobacteria. Those pores are expected to play a significant role in the water regime of soils with a dense microbial cover.

\section{Microbial cover affects water retention}

We observed that water-holding by soil at field capacity ( $\mathrm{pF} 2.5$; table 3 ) of samples with dense microbial cover is two to four times greater than that of bare soil 
(13\% vs. $3 \%$ on average; table 3 ). High resolution Cryo-SEM investigations of rewetted samples suggest that this high water-holding capacity is related to the hygroscopic properties of cyanobacteria polysaccharide material (fig. 5B). The spectacular size increase of cyanobacterial colonies in these samples, compared to dry samples (fig. 5A), is due to water absorption and subsequent swelling of cyanobacterial material (Galun et al., 1982; Campbell, 1979; Decho, 1990; Belnap and Gardner, 1993; Verrecchia et al., 1995). The polysaccharide sheath and extracellular secretions of cyanobacteria have been shown to absorb water in amounts several times their original volume, within a period of time ranging from a few to 30 minutes (Durrell and Shields, 1961; Campbell et al., 1989; Belnap and Gardner, 1993; Verrecchia et al., 1995; Kidron and Yair, 1997). Water absorption by swelling polysaccharide material allows cyanobacteria to withstand osmotic and matrix water stress (De Winder et al., 1989) and to recovery from drought periods (Ernst et al., 1987). This function also has a significant effect on increasing soil moisture and absorption of rainfall.

\section{Microbial cover affects water runoff}

The results of runoff measurements showed that, regardless of the type of soil cover, high runoff values were obtained. These results reflect the linear relationship between runoff and rainfall characteristics (fig. 2b; Casenave and Valentin, 1992). However our results also showed that water runoff is influenced by soil microbial cover; the amount of rainfall necessary for runoff generation on densely covered surfaces was lower than that on surfaces with thin microbial cover (fig. 2b). Final runoff measured on densely covered surfaces was also higher compared to values obtained on surfaces with low microbial cover (fig. 2b). 
The difference between the runoff characteristics of the two soil types is due to the difference in micromophological features (the presence of microbial pores; fig. 4) and the behaviour of microbial material upon wetting (fig. 5), i.e. repellence by hydrophobic polymers and water retention by polysaccharides. Hydrophobic polymers, which are abundant in dry soils with microbial cover, are known to prevent quick wetting of microbiotic crusts (Kidron et al., 1999; Malam Issa et al., 2001); their repellent effect ceases when soils become wet (Kidron et al., 1999). Earlier runoff generation on soils with dense microbial cover is also caused by the repellent effect of hydrophobic polymers at the beginning of rain events.

The polysaccharide material can have two types of behaviour upon wetting: limited swelling allowing water circulation in the microbial pores, or a large degree of swelling which reduces microbial pore size. Mazor et al. (1996) found that high concentrations of polysaccharides in sandy soils reduced the amount of water that penetrated the soil. By comparing microbiotic soil crusts containing different types of polysaccharides, these authors demonstrated that runoff generation at the surface of microbiotic soil crusts is positively correlated with the water holding capacity of polysaccharides. According to Verrecchia et al. (1995), pores between 4 and $40 \mu \mathrm{m}$ can be blocked when cyanobacterial polysaccharide material absorbs water and swells. The polysaccharide content of samples with a dense microbial cover is 1.5 to 3 times higher than that of samples with low microbial cover (Malam Issa et al., 2001). Our cryo-SEM images show the spectacular increase in the size of cyanobacterial colonies during wetting of microbiotic crusts due to the swelling of polysaccharide material in their mucilage (fig. 5a,b). This increase likely reduces the size of pores formed by the 
cyanobacteria, and subsequently induces the high amount of runoff found on welldeveloped microbial cover.

The roles of other factors, such as soil texture, in runoff generation on soil with microbial cover, may also be considered. In microbial soil crusts of Western Niger, soil texture is greatly affected by accretion of fine airborne particles which are trapped by cyanobacterial material. Accumulation of these particles, observed in thin soil sections, may also contribute to pore clogging and thus to runoff generation on soil with dense microbial cover.

These results agree with work supporting the positive role of microbial cover in runoff generation (Kidron et al., 1999, Eldridge et al., 2000, Yair, 2001). Soil surfaces with dense microbial cover in the Sahelian environment of Western Niger are thus potential areas which may contribute to capture limited water resources. Nevertheless, further studies are needed to evaluate the potential role of microbial cover in water redistribution in this environment. In particular, the impact of underlying physical crusts should be investigated, this influence could be different depending on the degree of microbial cover.

\section{CONCLUSION}

This study provides new data on the impact of microbiotic crusts on soil porosity and water dynamics in a Sahelian environment. Our findings confirm that microbiotic crusts are instrumental in generating high runoff. The results also show that polysaccharides and hydrophobic polymers of cyanobacteria affect the porosity of soil with a dense microbial cover. Runoff generation is under the control of the functioning 
of microbial pores, which itself is closely related to water holding capacity and the hydrophilic nature of cyanobacterial components. Hydrophobic polymers prevent quick wetting of soils with dense microbial cover, and the swelling of polysaccharide material reduces the effective porosity of soil, leading to early and high levels of runoff being generated on these soils. Thus, microbial soil covers could potentially contribute to form runoff-run-on systems that would help capture the limited water resources in the Sahelian environment of Western Niger. This could be beneficial for plant growth in tiger bush and fallow lands.

\section{ACKNOWLEDGEMENTS}

This study formed part of a research programme in West Africa (Projet Jachère) funded by the EU and IRD (Institut de Recherche pour le Développement). The authors gratefully acknowledge J-L. Rajot, Soumana, Alfari, Aboubacar, Abdoulaye and Moumouni for help with field work, and X. Dorothière, H. Gaillard, A. Genty, C. Le Lay, and A. Richard for their skilled technical assistance. The authors thank G. J. Kidron, Leigh Gebbie and an anonymous reviewer for their constructive suggestions and correction of the manuscript and the English.

\section{REFERENCES}

Ambouta, J.M.K., 1984. Contribution à l'édaphologie de la brousse tigrée de l'ouest nigérien. Thèse de docteur ingénieur, Université Nancy I, France.

Ambouta, J.M.K., 1997. Définition et caractérisation des structures de végétation contractée au Sahel : cas de la brousse tigrée de l'ouest nigérien. In J.-M. d’Herbès, J.M.K. Ambouta, R. Peltier (Editors.), Fonctionnement et gestion des écosystèmes forestiers contractés sahéliens. John Libbey Eurotext, Paris, pp. 41-57. 
Belnap, J., Gardner, J.S., 1993. Soil microstructure in soils of the Colorado Plateau: the role of the cyanobacterium Microcoleus vaginatus. Great Basin Naturalist, 53: 40-47.

Belnap, J., Eldridge, D.J., 2001. Disturbance and recovery of biological soil crusts. In: J. Belnap, O.L. Lange (Editors), Biological soil crusts: structure, function and management. Springer, Berlin, pp. 363-383.

Belnap, J., 2006. The potential roles of biological soil crusts in dryland hydrologic cycles. Hydrological Processes, 20: 3159-3178.

Campbell, S.E., 1979. Soil stabilization by prokaryotic desert crust: implications for Precambrian land biota. Origin of Life, 9: 335-348.

Campbell, S.E., Seeler J.S., Golubic S., 1989. Desert crust formation and soil stabilization. Arid Soil Res. Rehab., 3: 217-228.

Casenave, A., Valentin, C., 1992. A runoff capability classification system based on surface features criteria in semi-arid areas of West Africa. J. Hydrol., 130: 231-249.

Cornet, A., 1992. Relations entre la structure spatiale des peuplements végétaux et le bilan hydrique des sols de quelques phytocénoses en zone aride. In E. Le Floc'h, M. Grouzis, A. Cornet, J.-C. Bille (Editors.), L'aridité, une contrainte au développement. ORSTOM éditions, coll. Didactiques, Paris, France, pp. 241-261.

Courault, D., D'Herbes, J.M., Valentin, C., 1990. Le bassin versant de Sama Dey : premières observations pédologiques et phyto-écologiques. ORSTOM, Paris.

Danin, A., Bar-Or, Y., Dor, I, Yisraeli, T., 1989. The role of cyanobacteria in stabilisation of sand dunes in Southern Israel. Ecologia Mediterranea, XV: 55-64.

Decho, A.W., 1990. Microbial exopolymer secretions in ocean environments: their role(s) in food webs and marine processes. Oceanogr. Mar. Biol., 28: 73-153. 
Défarge, C., Malam Issa, O., Trichet, J., 1999. Apports du Cryo-microscope électronique à balayage à émission de champ à l'étude des matières organiques et des relations organo-minérales naturelles. II. Application aux croûtes microbiotiques des sols. Comptes Rendus Acad. Sciences, 328: 591-597.

De Winder, B., Matthijs, H.C.P, Mur, L.R., 1989. The role of water retaining substrata on the photosynthetic response of three drought tolerant phototrophic micro-organisms isolated from a terrestrial habitat. Archives of Microbiology, 152: 458-462.

Durell, L.W., Shields, L.M., 1961. Characteristics of soil algae relating to crust formation. Transactions of the American Microscopical Society, 80: 73-79.

Eldridge, D.J., 2001. Biological soil crusts and water relations in Australia deserts. In: J. Belnap, O.L. Lange (Editors), Biological soil crusts: structure, function and management. Springer, Berlin, pp. 315-325.

Eldridge, D.J., Tozer, M.E., Slangen, S., 1997. Soil hydrology is independent of microphytic crust cover: Further evidence from wooded semiarid Australian rangeland. Arid Soil Res. Rehab., 11: 113-126.

Eldridge, D.J., Zaady, E., Shachak, M., 2000. Infiltration through three contrasting biological soil crusts in patterned landscape in the Negev, Israel. Catena, 40: 323-336.

Ernst, A., Chen, T., Böger, P., 1987. Carbohydrate formation in rewetted terrestrial cyanobacteria. Oecologia, 72: 574-576.

Galun, M., Burbick, P., Garty, J., 1982. Structural and metabolic diversity of two desert lichen populations. J. Hattori Bot. Lab., 53, 321-324.

Greigert, J., 1966. Description des formations crétacés et tertiaires du bassin des Iullemmeden (Afrique occidentale). Publications de la Direction Mines et Géologie, Niamey, Niger. 
Kidron, G.J., Yair, A., 1997. Rainfall-runoff relationship over encrusted dune surfaces, Nizzana, Western Negev, Israel. Earth Surf. Processes. Landf., 22, 1169-1184.

Kidron, G.J., Yaalon, D.H., Vonshak, A., 1999. Two causes of runoff initiation on microbiotic crusts : hydrophobicity and pore clogging. Soil Science, 164: 18-27.

Le Barbé, L. and Lebel, T., 1997. Rainfall climatology of the HAPEX-Sahel region during the years 1950-1990. J. Hydrol., 188-189: 43-73.

Li, X.-R., Wang, X.-P., Li, T., Zhang, J.-G., 2002. Microbiotic soil crust and its effect on vegetation and habitat on artificially stabilised desert dunes in Tengger Desert, North China. Biol. Fertil. Soils, 35: 147-154.

Loope, W.L., Gifford, G.F., 1972. Influence of a soil microfloral crust on select properties of soils under pinyon-juniper in southeastern Utah. Journal of Soil and Water Conservation, 27: 164-167.

Maestre, F.T., Huesca, M., Said, E., Bautista, S., Cortina, J., 2002. Infiltration, penetration resistance and microphytic crust composition in contrasted microsites within a Mediterranean semi-arid steppe. Soil Biol. Biochem., 34: 895-898.

Malam Issa, O., Trichet, J., Défarge, C., Couté, A., Valentin, C., 1999. Morphology and microstructure of microbiotic soil crusts on a tiger bush sequence (Niger, Sahel). Catena, 37: 175-196.

Malam Issa, O., Le Bissonnais, Y., Défarge, C., Trichet, J., 2001. Role of a microbial cover on structural stability of a sandy soil in Sahelian part of western Niger. Geoderma, 101: 15-30.

Mazor, G., Kidron, G.J., Vonshak, A., Abeliovich, A., 1996. The role of cyanobacterial exopolysaccharides in structuring desert microbial crusts. FEMS Microbiology Ecology, 21: 121-130. 
Pérez, F.L., 1997. Microbiotic crusts in the high equatorial Andes, and their influence on paramo soils. Catena, 31: 173-198.

Stanier, R.Y., Cohen-Bazire, G., 1977. Phototrophic prokaryotes: the cyanobacteria. Annu. Rev. Microbiol., 31: 225-274.

Valentin, C., 1995. Sealing, crusting and hardesetting soils in sahelian agriculture. In H.B. SO, G.D. Smith, S.R. Raine, B.M. Schafer, R.J. Loch (Editors.), Sealing, Crusting and Hardsetting Soils: Productivity and Conservation. Australian Society of Soil Science, Brisbane, pp. 53-76.

Valentin, C., Bresson L.-M., 1992. Morphology, genesis and classification of surface crusts in loamy and soils. Geoderma, 55: 225-245.

Valentin, C., d'Herbes, J.-M., Poesen, J., 1999. Soil and water components of banded vegetation patterns. Catena, 37: 1-24.

Verrecchia, E., Yair, A., Kidron, G.J., Verrecchia, K., 1995. Physical properties of the psammophile cryptogamic crust and their consequences to the water regime of sandy soils, north-western Negev desert, Israël. Journal of Arid Environments, 29: 427-437.

Warren, S.D., 2001. Biological soil crusts and hydrology in North American deserts. In: J. Belnap, O.L. Lange (Editors), Biological soil crusts: structure, function and management. Springer, Berlin, pp. 327-337.

Williams, J.D., Dobrowolski, J.P., West, N.E., 1999. Microbiotic crust influence on Unsaturated hydraulic conductivity. Arid Soil Res. Rehab., 13: 145-154.

Yair, A., 2001. Effects of biological soil crusts on water redistribution in the Negev desert, Israel: a case study in longitudinal dunes. In: J. Belnap, O.L. Lange (Editors), Biological soil crusts: structure, function and management. Springer, Berlin, pp. 303314. 


\section{FIGURE CAPTIONS}

Figure 1: Mean geomorphic elements found at Banizoumbou (modified from Courault et al., 1990).

Figure 2a: Rainfall events throughout1996.

Figure 2b: Relationship between rainfall depth and runoff at the surface of soils with dense (dotted line) and thin microbial cover (box).

Figure 3: Cumulative pore volume curves for microbiotic crust samples and samples taken below these same crusts. Note the difference between microbiotic crust samples with dense microbial cover (cross) and thin microbial cover (square) and samples from the underlying horizon (round). Note similar trends between microbiotic crust samples from soil with thin microbial cover and samples from under crusts.

Figure 4: SEM micrographs of the surface of soil covered with a dense microbial layer. View showing the network of cyanobacterial filaments (F) enmeshing soil mineral particles (Q). Note the presence of pores due to microbial cover, including rounded pores delineated by filaments (arrows) and elongated pores between adjoining filaments.

Figure 5: Cryo-SEM micrographs of the surface of soil with a dense cover of Nostoc cyanobacteria. The filaments are grouped in globose colonies (B). The surface also comprises filaments (F) of other cyanobacteria, cyanobacteria extracellular polymer secretions (EPS), and soil mineral particles (Q). (A) View of dry sample. (B) View of sample after rewetting.

Figure 6: Photomicrographs of thin sections. (A) View of the soil profile with a dense microbial cover. The profile shows a continuous layer formed by living cyanobacteria 
associated with mineral particles (at the top), alternation of layers of fine (Pl) and coarse (Q) particles, and ancient microbiotic crusts (arrows). Note the close fabric formed of coarse and fine particles associated with cyanobacterial filaments (F). The sub-crust (at the bottom) consists of coarse particles (Q) and shows a loose fabric with large pores $(\mathrm{V})$.

(B) View of the soil profile with thin microbial cover. The profile shows a superficial discontinuous layer of living cyanobacteria (arrowed) associated with fine mineral particles. Few cyanobacterial filaments (F) were observed among the soil profile. The crust-underlying horizon (at the bottom) consists of aggregates (A), coarse (Q) and fine (Pl) particles, and shows a loose fabric with large pores (V). 
Table 1: textural characteristics of the studied soil.

\begin{tabular}{lccccc}
\hline & Clay & Fine & Coarse silt & Fine sand & Coarse sand \\
Particle-size fraction & $0-2 \mu \mathrm{m}$ & $2-20 \mu \mathrm{m}$ & $20-50 \mu \mathrm{m}$ & $50-200 \mu \mathrm{m}$ & $200-2000 \mu \mathrm{m}$ \\
\hline Mean values (\%) & 4.8 & 3.6 & 1.6 & 28.1 & 62.2 \\
Standard errors & 0.5 & 1.1 & 0.6 & 4.8 & 7.6 \\
\hline
\end{tabular}

Table 2: Soil surface conditions of the experimental plots: initial and value of microbial cover measured at the beginning, during and at the end of runoff measurements periods.

\begin{tabular}{ccccc} 
& \multicolumn{4}{c}{ Period of observations } \\
\cline { 2 - 5 } & Initial (15/06/96) & $16 / 07 / 1996$ & $04 / 09 / 96$ & $23 / 10 / 1996$ \\
\hline $\begin{array}{c}\text { Soil with } \\
\text { dense microbial cover }\end{array}$ & 80 & 62 & 50 & 35 \\
\hline $\begin{array}{c}\text { Soil with } \\
\text { thin microbial cover }\end{array}$ & 14 & 3 & 4 & 5 \\
\hline
\end{tabular}

Table 3: Water retention capacity and total pore volume measured by mercury porosimetry of samples with and samples devoid of microbial cover. (Mean values of 2 to 4 replicates).

\begin{tabular}{cccc}
\cline { 2 - 4 } & $\begin{array}{c}\mathrm{pF} \mathrm{2.5} \\
\%\end{array}$ & $\begin{array}{c}\mathrm{pF} \mathrm{4.2} \\
\%\end{array}$ & $\begin{array}{c}\text { Total pore volume } \\
\mathrm{mm}^{3} \mathrm{~g}^{-1}\end{array}$ \\
\hline $\begin{array}{c}\text { Soil with } \\
\text { dense microbial cover }\end{array}$ & $13 \pm 0.7$ & $3 \pm 0.7$ & $280 \pm 10$ \\
\hline $\begin{array}{c}\text { Soil with } \\
\text { thin microbial cover }\end{array}$ & $7 \pm 0.5$ & $2 \pm 0.3$ & $210 \pm 4$ \\
\hline $\begin{array}{c}\text { horizon underlying } \\
\text { the crust }\end{array}$ & $3 \pm 0.6$ & $2 \pm 0.3$ & $22 \pm 8$ \\
\hline
\end{tabular}


Figure 1:

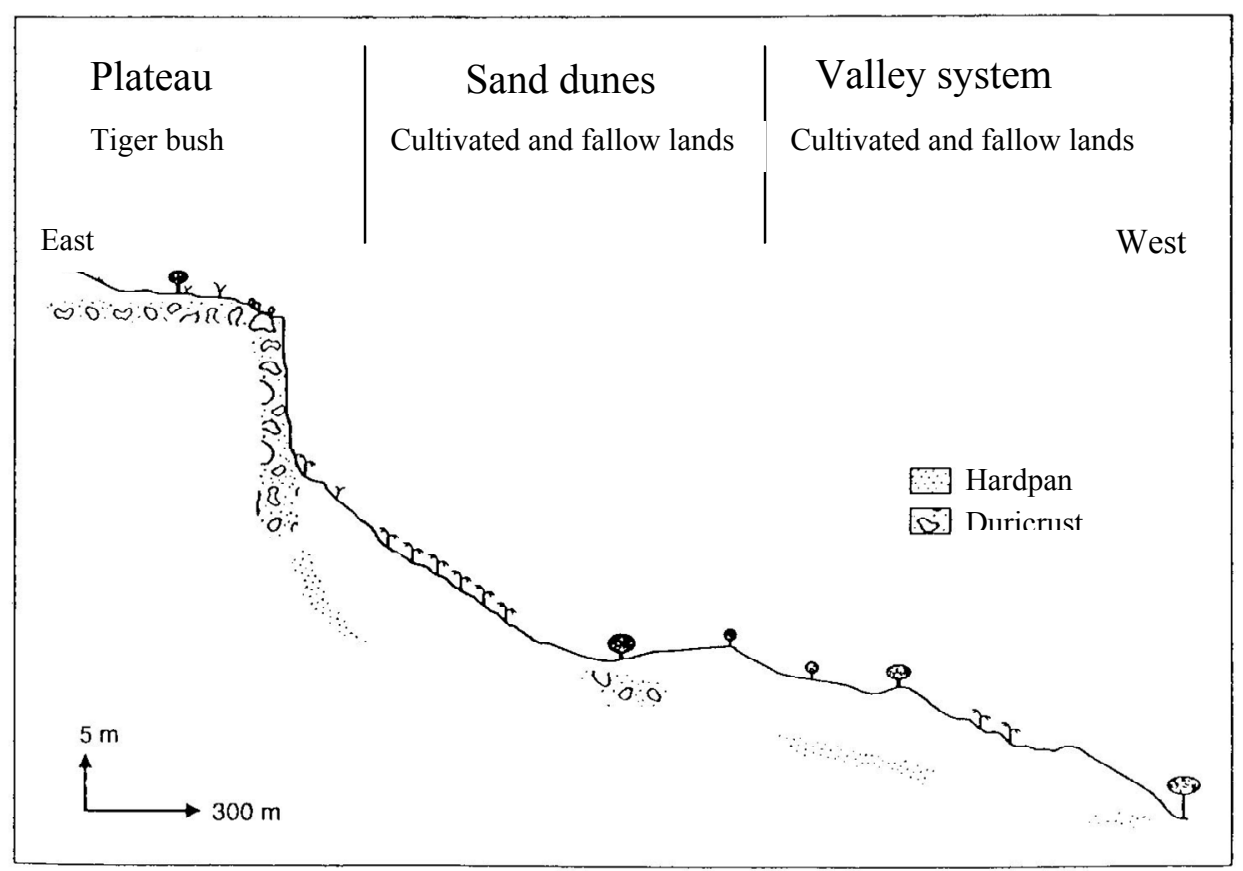

Figure 2a :

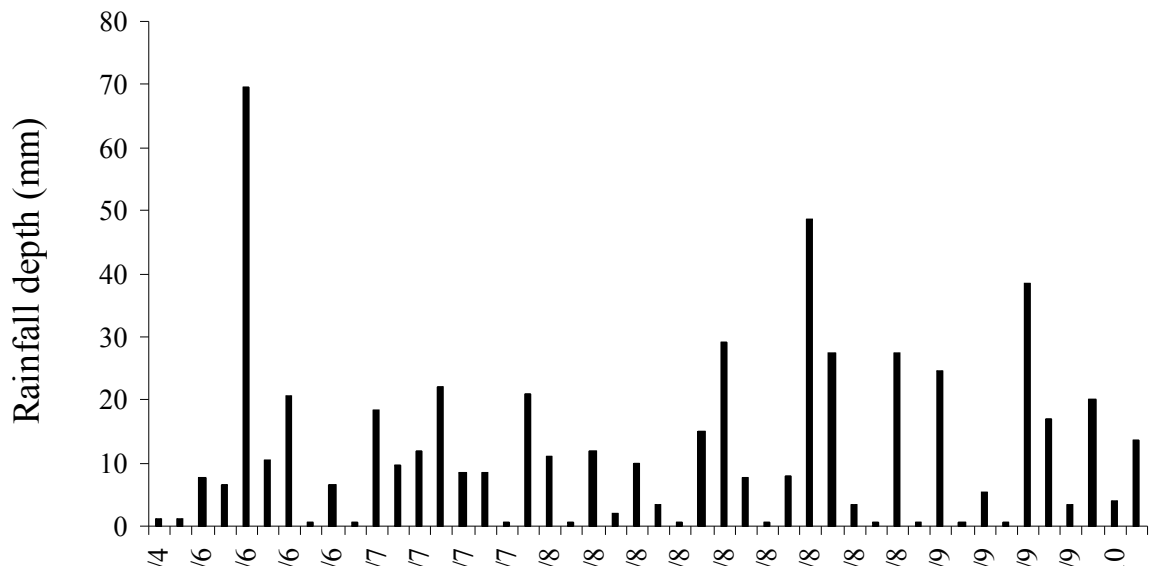

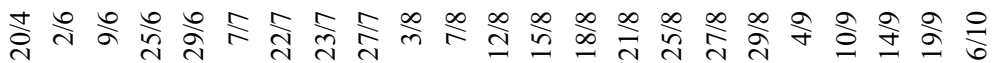

Date (day/month) 
Figure $2 b$ :

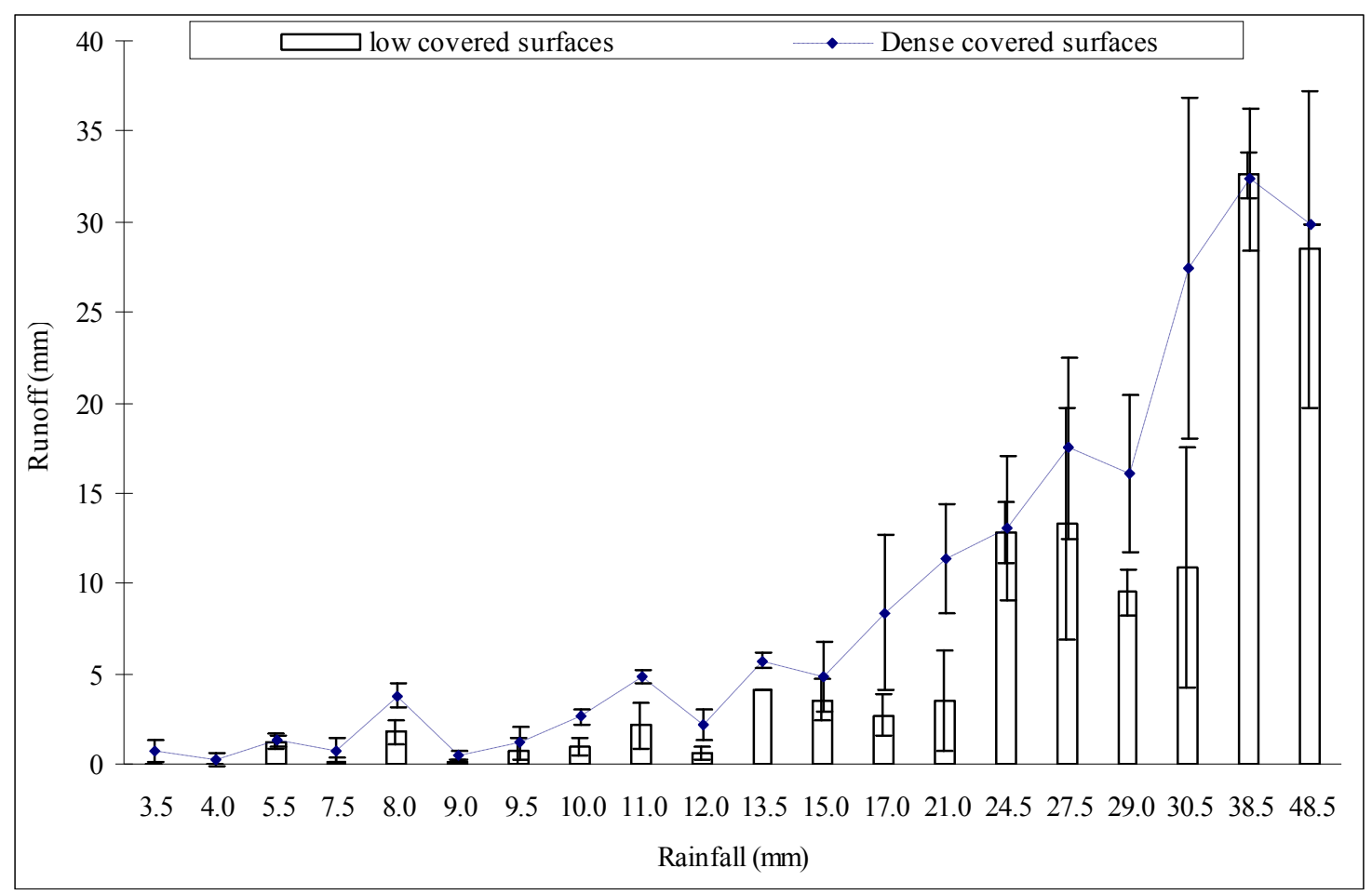

Figure 3

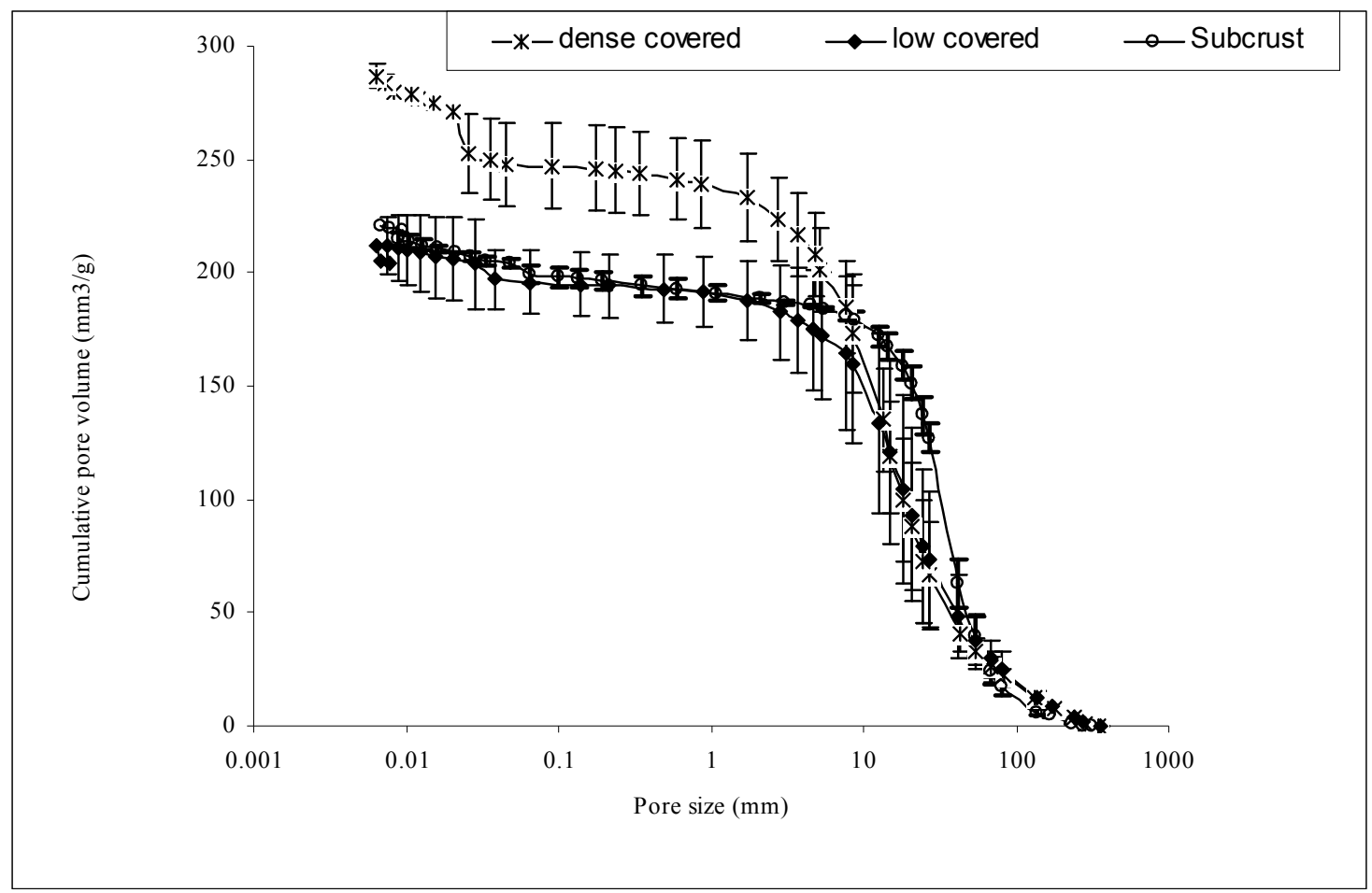


Figure 4

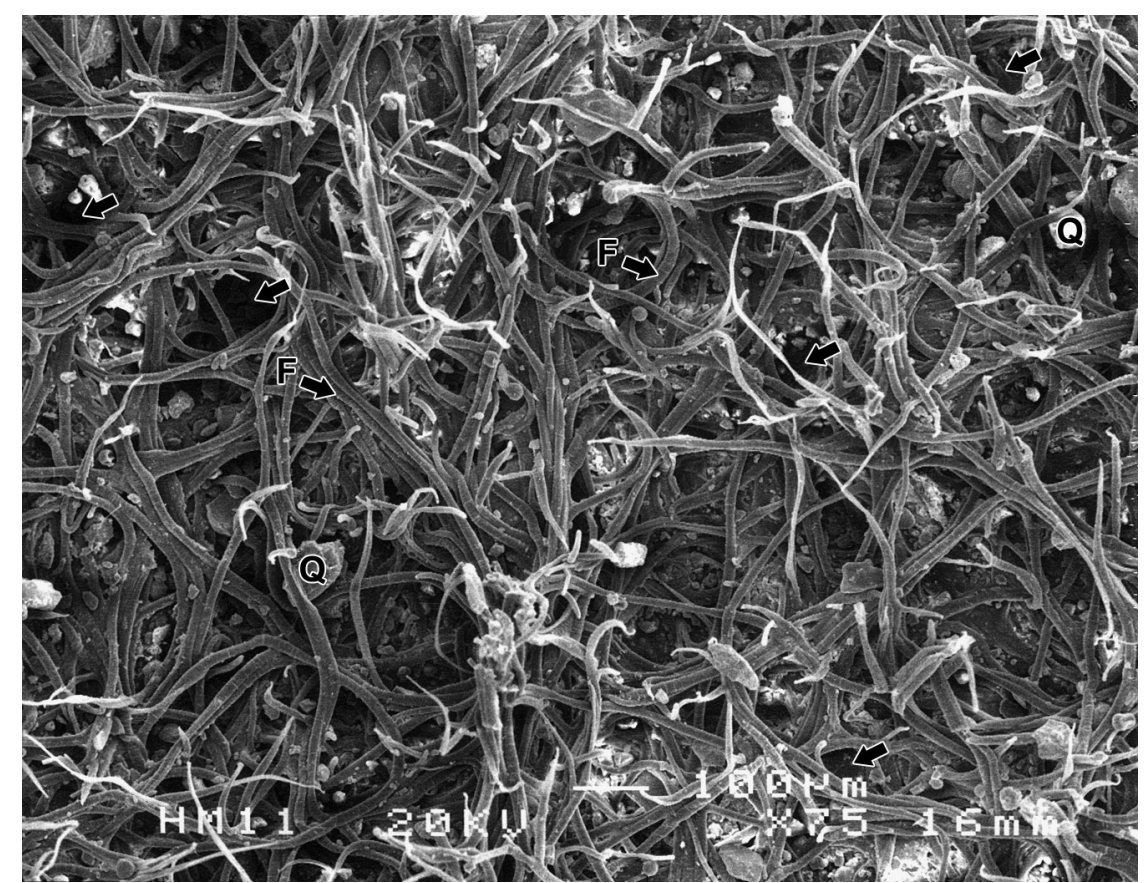


Figure 5A

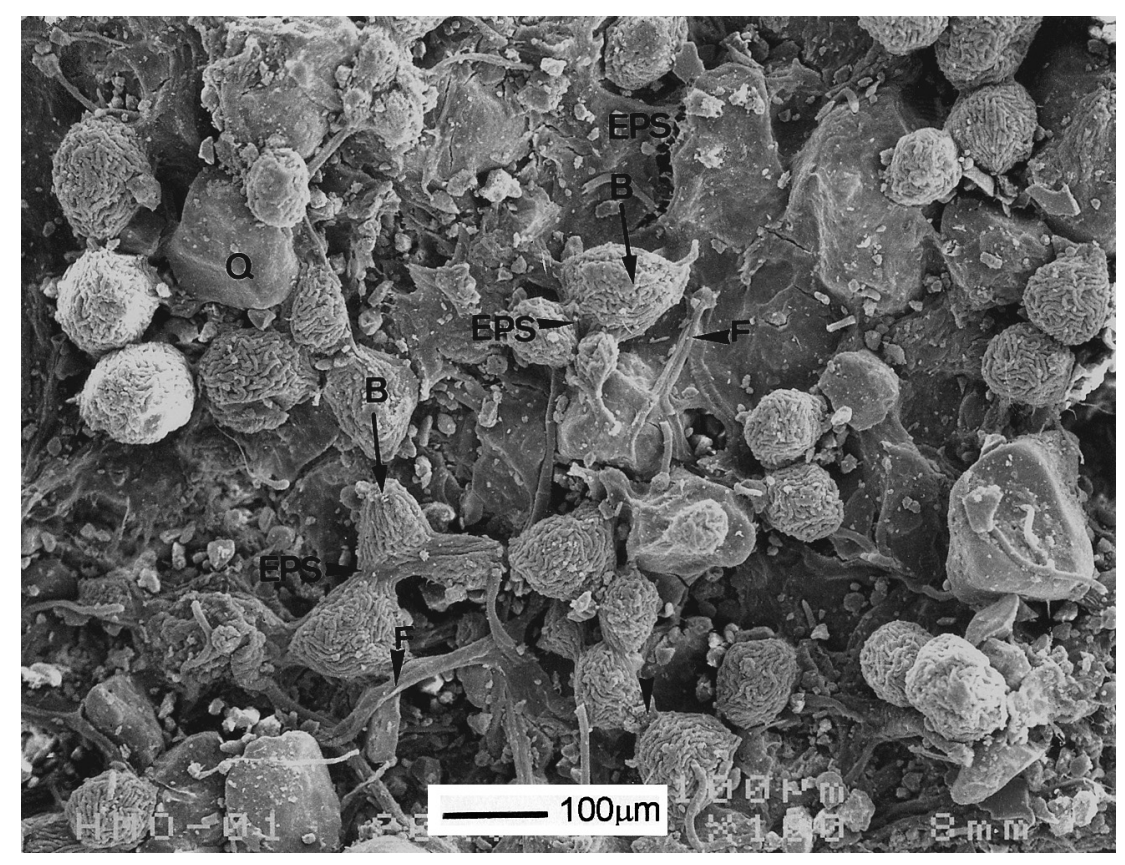

Figure 5B

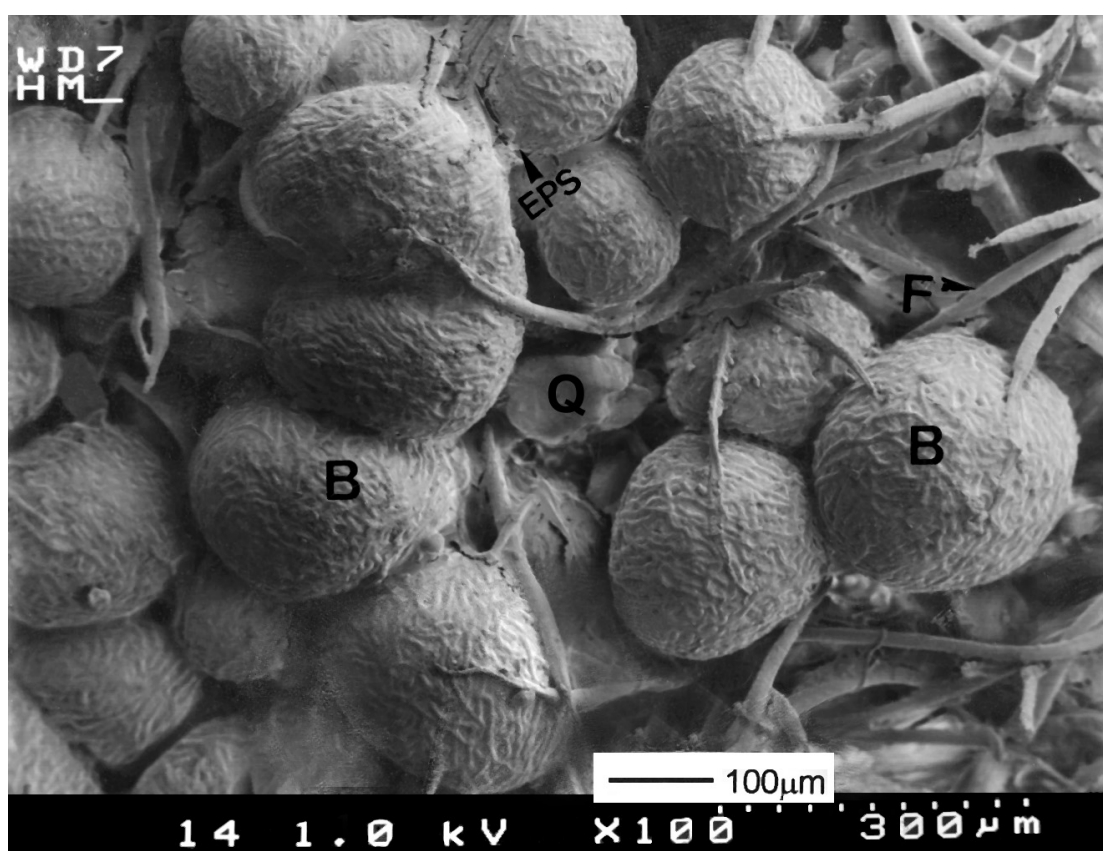


Figure 6A

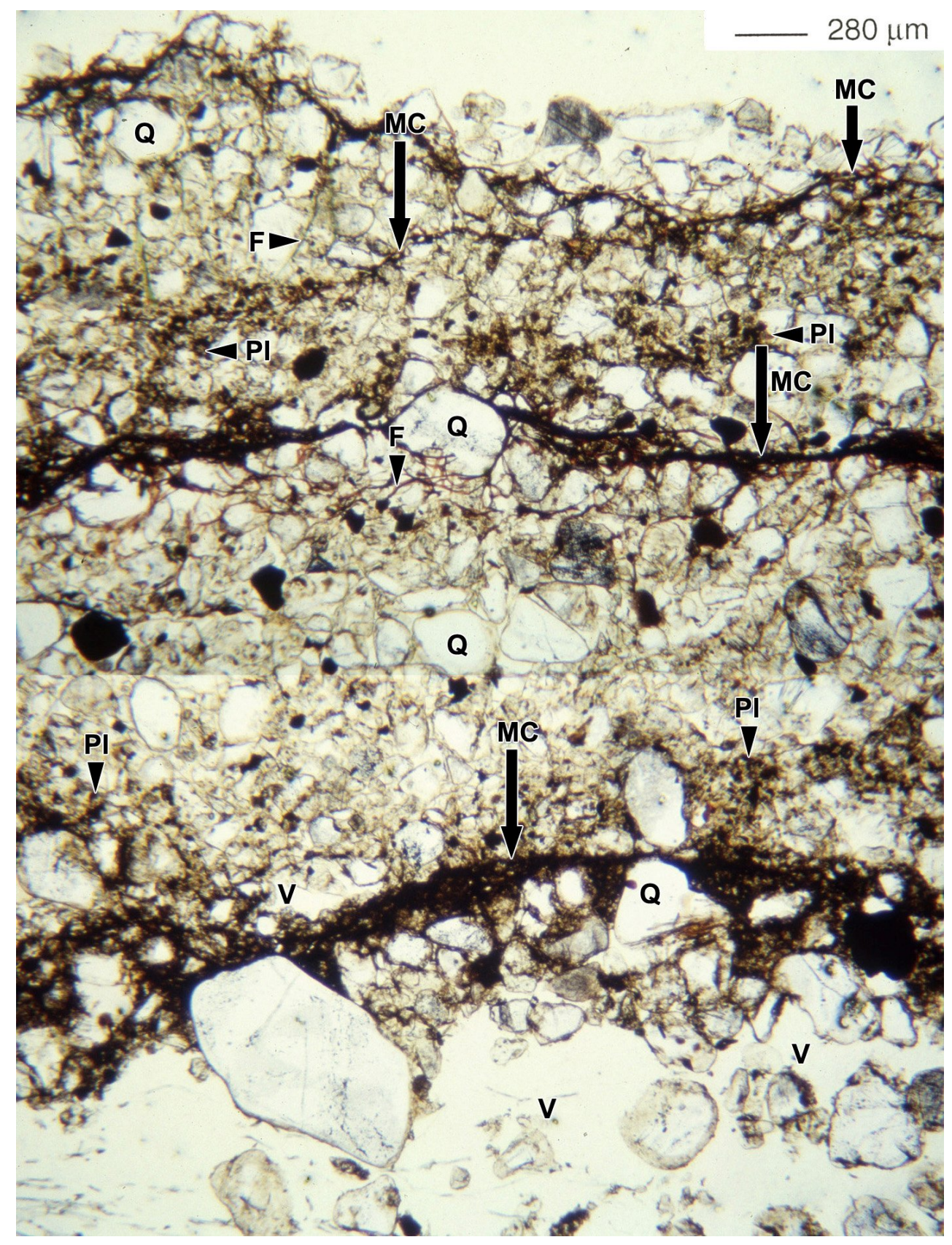


Figure 6B
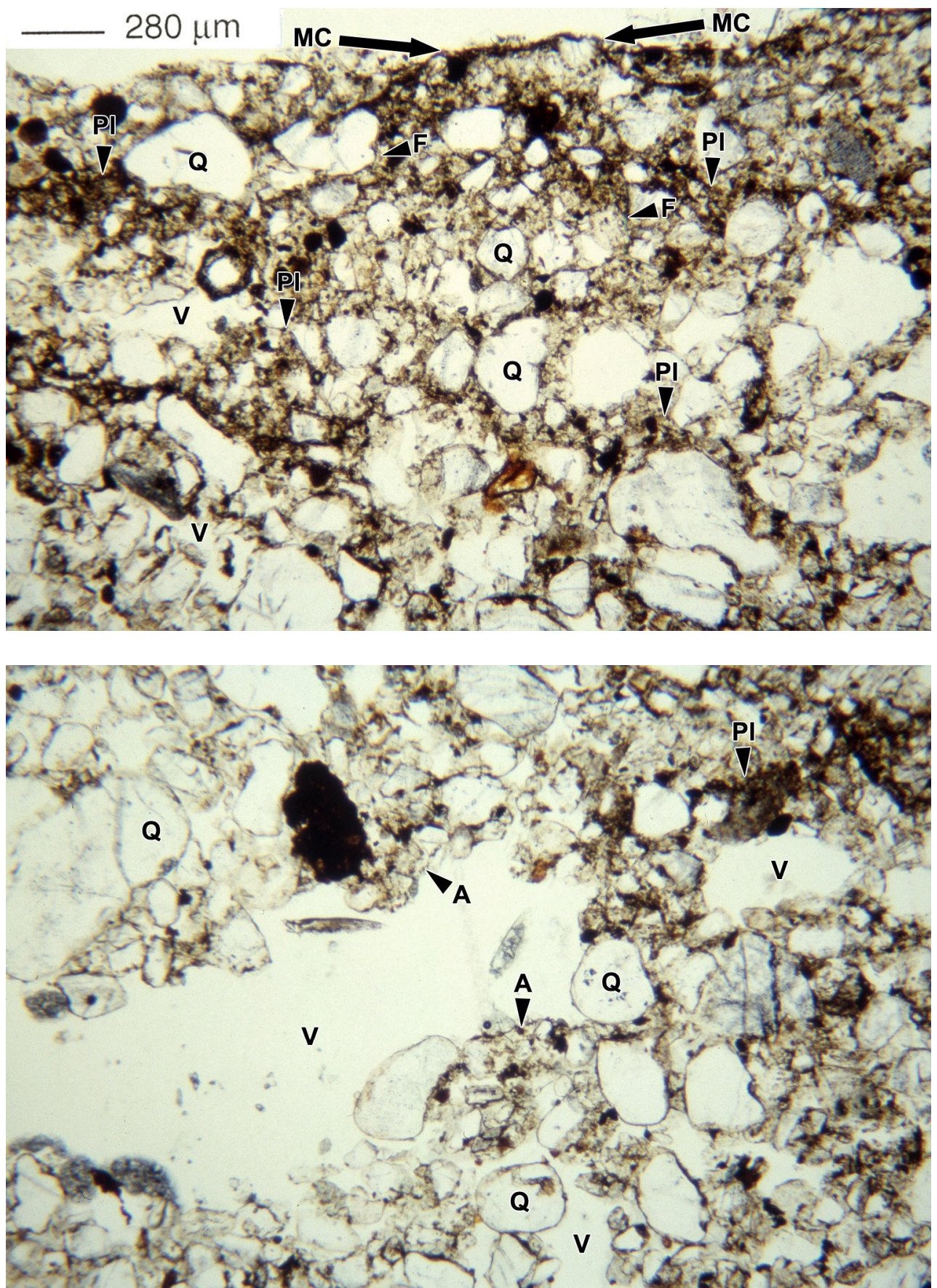